\title{
Elevated Insulin Receptor Content in Human Breast Cancer
}

\author{
Vincenzo Papa, ${ }^{\star \|}$ Vincenzo Pezzino, * Angela Costantino, * Antonio Belfiore, ${ }^{*}$ Dario Giuffrida, ${ }^{*}$ Lucia Frittitta, * \\ Gabriella B. Vannelli, ${ }^{\ddagger}$ Richard Brand, ${ }^{5}$ Ira D. Goldfine," and Riccardo Vigneri* \\ ${ }^{*}$ Cattedra di Endocrinologia and Cattedra di Scienza delle Costituzioni dell'Università di Catania, Ospedale Garibaldi, Piazza S.M. di \\ Gesù, 95125 Catania, Italy; ${ }^{\ddagger}$ Dipartimento di Anatomia Umana e Istologia dell'Università di Firenze, Policlinico Careggi, 50110 \\ Firenze, Italy; ${ }^{\S}$ School of Public Health, University of California, Berkeley, California 94720; "Division of Diabetes and Endocrine \\ Research, Mount Zion Medical Center of the University of California, San Francisco, California 94120; \\ and 'Departments of Medicine and Physiology, University of California, San Francisco, California 94143
}

\begin{abstract}
The growth of breast cancer cells is under the regulation of hormones, growth factors, and their receptors. In the present study, we have employed a new, sensitive, and specific radioimmunoassay for the direct measurement of insulin receptors in surgical specimens of breast cancers. In 159 specimens the insulin receptor content was $6.15 \pm 3.69 \mathrm{ng} / 0.1 \mathrm{mg}$ protein. This value was more than sixfold higher than the mean value found in both 27 normal breast tissues obtained at total mastectomy $(0.95+0.68, P<0.001)$ and in six normal specimens obtained from reduction mammoplasty $(0.84 \pm 0.78, P$ $<0.001)$. The insulin receptor content in breast cancer tissues was also higher than in any normal tissue investigated including liver (Pezzino, V., V. Papa, V. Trischitta, A. Brunetti, P. A. Goodman, M. K. Treutelaar, J. A. Williams, B. A. Maddux, R. Vigneri, and I. D. Goldfine. 1989. Am. J. Physiol. 257:E451457). The insulin receptor in breast cancer retained its ability to both bind insulin and undergo insulin-induced tyrosine kinase activation. Immunostaining of the specimens revealed that the insulin receptor was present in malignant epithelial cells, but was not detected in stromal and inflammatory cells.

Univariant analysis revealed that the insulin receptor content of the tumors correlated positively with tumor size $(P$ $=0.014)$, histological grading $(P=0.030)$, and the estrogen receptor content $(P=0.035)$. There were no significant correlations between insulin receptor content and the age, body weight, menopausal status, and nodal involvement of the patients. These studies indicate, therefore, that the insulin receptor content is increased in breast cancers and raise the possibility that the insulin receptor may have a role in the biology of these tumors. (J. Clin. Invest. 1990. 86:1503-1510.) Key words: breast cancer $\bullet$ insulin receptor $\bullet$ insulin-like growth factor
\end{abstract}

\section{Introduction}

Human and animal breast carcinomas have receptors for steroid and peptide hormones (1-9), and both in vitro and in vivo studies $(1,10-15)$ indicate that their growth is hormone dependent. Various studies have demonstrated that there is a greater long term survival in patients with breast carcinomas

Received for publication 16 October 1989 and in revised form 12 July 1990.

J. Clin. Invest.

(c) The American Society for Clinical Investigation, Inc.

$0021-9738 / 90 / 11 / 1503 / 08 \quad \$ 2.00$

Volume 86, November 1990, 1503-1510 that have receptors for estrogen and progesterone, and in these patients tumor growth can be decreased by a variety of manipulations that alter steroid hormone levels (16-19). However, some patients with breast carcinomas containing high concentration of estrogen and progesterone receptors do not show beneficial responses to hormonal therapy $(16,20)$. One explanation for this unresponsiveness is that the tumor cells, for a variety of reasons, may have escaped from hormonal regulation. A second explanation is that these tumors are heterogeneous and contain subpopulations of cells without steroid hormone receptors. A third explanation is that tumor cells contain receptors for other classes of hormones such as polypeptide hormones and growth factors, and that these hormones, either by themselves or in combination with steroid hormones, stimulate tumor growth $(1,21)$. For this reason, it is of importance to identify in breast cancer cells the presence of receptors for other hormones and growth factors that may influence the behavior/evolution of the tumor.

Insulin regulates the growth and metabolism of animal breast cancer cells both in vivo and in vitro (22-24) and human breast cells in vitro $(23,25-28)$. Moreover, several human breast cancer cell lines in permanent culture have specific, high-affinity receptors for insulin $(29,30)$, and the presence of insulin receptors has been reported in frozen specimens of human breast carcinomas $(4,31)$. For several reasons, however, the importance of these observations is unclear. First, a quantitative comparative analysis between the number of receptors in tumor cells versus normal mammary gland tissue has not been carried out. Second, in human cancers, correlations between insulin receptor content, and established prognostic parameters of cancer evolution including estrogen and progesterone receptor content, and tumor size and grading have not been made.

Recently, we have developed a highly sensitive and specific RIA for the insulin receptor (32). This assay allows the precise quantitation of the insulin receptor in very small tissue specimens and does not significantly cross react $(<3 \%)$ with the related insulin-like growth factor (IGF-I) ${ }^{1}$ receptor (32). In the present study, using this assay, we have measured the insulin receptor content of human breast carcinomas and corresponding normal mammary gland tissue. In the breast cancer tissue, we have localized the cell type containing the insulin receptors, and have analyzed the functional properties of these receptors. Further, we have correlated the tissue content of insulin receptors with indices of tumor aggressiveness including biochemical and morphological features.

1. Abbreviations used in this paper: IGF-I, insulin-like growth factor; IR, insulin receptor. 


\section{Methods}

\section{Materials}

The following materials were purchased: BSA, human gamma globulin, porcine insulin, bacitracin, PMSF, Triton X-100, polyethyleneglycol (PEG), charcoal, poly (Glu-Tyr, 4:1), anti-mouse IgG peroxidase conjugate, and dietylstilbestrol from Sigma Chemical Company (St. Louis, MO); wheat germ agglutinin-agarose and nonimmune rabbit serum from Miles Scientific (Naperville, IL); anti-rabbit gamma globulin from Antibodies Inc. (Davis, CA); $\mathrm{A}_{14^{4}}{ }^{125} \mathrm{I}$-insulin (sp act, 360 $\mu \mathrm{Ci} / \mu \mathrm{g}),{ }^{125} \mathrm{I}$-labeled Bolton-Hunter reagent $(2,200 \mathrm{Ci} / \mathrm{mMol}),\left[\gamma-{ }^{32}\right.$ P]ATP (1-3 Ci/mMol), tritiated estradiol, tritiated ORG 2058 and unlabeled ORG 2058 from Amersham (Amersham, UK); dextran T 70 from Pharmacia Fine Chemicals (Uppsala, Sweden). A mouse monoclonal antibody specific for the human insulin receptor $\alpha$-subunit, was prepared as previously described (33). Diaminobenzidine was obtained from BDH Chemical Ltd. (Poole, UK). All other reagents were of analytical grade.

Highly purified insulin receptors were obtained from human placenta as previously described (34) by use of sequential monoclonal antibody agarose and wheat germ agglutinin-agarose affinity chromatography. Antiinsulin receptor antiserum was raised in a rabbit after repeated immunizations with purified human placental insulin receptors as previously described (34).

MCF-7 cells were kindly provided by Dr. I. Perroteau (University of Torino, Turin, Italy).

\section{Tissues}

The following pathological and normal tissue specimens were examined: 159 breast cancers and 42 nonmalignant mammary samples ( 9 fibroadenomas and 33 normal breast tissues). ${ }^{2}$ The normal breast tissue specimens included: 27 normal breast tissue specimens obtained at total mastectomy from patients with breast carcinoma; and 6 normal breast tissues from patients undergoing reduction mammoplasty. Six papillary thyroid cancers and seven nonmalignant thyroid tissue samples (five normal thyroid and two Graves' disease specimens).

Histologic sections of the breast tumors were classified according to the World Health Organization criteria (35). The grading of infiltrating ductal and mixed carcinomas was assessed on a scale of 1 (well-differentiated) to 3 (poorly differentiated) taking into account the degree of tubular differentiation, the nuclear pleomorphism and the mitotic activity according to Bloom and Richardson (36). On the basis of tumor size breast cancers were also classified $T_{1}$ (maximum diameter $\leq 2$ $\mathrm{cm}), \mathrm{T}_{2}(>2 \mathrm{~cm}$, but $<5 \mathrm{~cm})$, and $\mathrm{T}_{3}(>5 \mathrm{~cm})$.

\section{Methods}

Sample preparation. Specimens were collected at surgery, dissected free of fat and connective tissue, transported to the laboratory in dry ice, and frozen immediately in liquid nitrogen. Informed consent was obtained from all patients. To prepare extracts for radioimmunoassay, tissues were minced, suspended at $0.1-0.2 \mathrm{~g} / \mathrm{ml}$ in $50 \mathrm{mM}$ Hepes buffer, pH 7.6, containing $1 \mathrm{mg} / \mathrm{ml}$ bacitracin and $1 \mathrm{mM} \mathrm{PMSF}$, and homogenized with a Polytron homogenizer (Kinematica, Lucern, Switzerland) at $4^{\circ} \mathrm{C}$. The homogenized material was then incubated with Trition X-100 ( $1 \%$ final concentration) for $60 \mathrm{~min}$ at $4^{\circ} \mathrm{C}$ under continuous shaking. The solubilized material was then centrifuged at

2. The 159 breast cancer specimens were obtained as a consecutive series of breast cancer tissues sent to the Cattedra di Endocrinologia at the University of Catania for estrogen and progesterone receptor measurements. Most specimens were from patients operated on at the Division of Oncology, the main center for breast cancer surgery in Catania, where patients were either referred by general practitioners or directly seen at the outpatient clinic. A small percentage of specimens, directly sent by peripheral hospitals, was also included. Informed consent was obtained from all patients whose tissue was studied.
$10,000 \mathrm{~g}$ for $5 \mathrm{~min}$ at $4^{\circ} \mathrm{C}$ in a microfuge (Beckman Instruments Inc. Palo Alto, CA) and the supernatant frozen at $-80^{\circ} \mathrm{C}$ until assayed. MCF-7 human cultured breast cancer cells were solubilized for radioimmunoassay as previously described for cultured cells (32).

${ }^{125}$ I-insulin binding to solubilized receptors. Binding studies were carried out with solubilized insulin receptors $(30 \mathrm{ng})$ in a final volume of $0.5 \mathrm{ml}$ of buffer containing $100 \mathrm{mM}$ Hepes (pH 7.9), $120 \mathrm{mM} \mathrm{NaCl}$ $1.2 \mathrm{mM} \mathrm{MgCl} 2,2 \mathrm{mM} \mathrm{MnCl}, 2.5 \mathrm{mM} \mathrm{KCl}, 0.5 \mathrm{mM} \mathrm{Na}$ acetate, 1 $\mathrm{mM}$ EDTA, $1 \mathrm{mg} / \mathrm{ml}$ bacitracin, and $10 \mathrm{mg} / \mathrm{ml} \mathrm{BSA} .{ }^{125} \mathrm{I}$-insulin $(66$ pM) was added in the presence or absence of excess unlabeled insulin $(166 \mathrm{nM})$ and incubated for $18 \mathrm{~h}$ at $4^{\circ} \mathrm{C}$. Carrier human gamma globulin $(2 \mathrm{mg} / \mathrm{ml})$ was added to each tube, $0.5 \mathrm{ml}$ of $22 \%$ PEG 6,000 was then added and incubated for $15 \mathrm{~min}$ at $4^{\circ} \mathrm{C}$. After centrifugation, precipitates were washed once with $11 \%$ PEG, recentrifuged, the supernatants discarded, and the pellets counted. Specific binding was obtained by subtracting binding with ${ }^{125}$ I-insulin plus unlabeled insulin from binding with ${ }^{125} \mathrm{I}$-insulin alone.

Insulin receptor $R I A$. The insulin receptor radioimmunoassay was performed as previously described (32). Briefly, the following reagents were added to $9 \times 70$ plastic tubes: $0.2 \mathrm{ml}$ of either solubilized tissues, or buffer ( $50 \mathrm{mM}$ Hepes, $\mathrm{pH} 7.6,150 \mathrm{mM} \mathrm{NaCl}, 0.1 \%$ Triton X-100, $0.2 \% \mathrm{BSA}$, and $0.2 \mathrm{mM}$ PMSF) containing $0-15 \mathrm{ng}$ of unlabeled receptor; $0.1 \mathrm{ml}$ of the same buffer containing the antiinsulin receptor antiserum (final dilution 1:100,000) and nonimmune rabbit serum (final dilution 1:400). After $16 \mathrm{~h}$ at $4^{\circ} \mathrm{C}, 6,000-8,000 \mathrm{cpm}$ of ${ }^{125} \mathrm{I}-\mathrm{la}$ beled insulin receptor labeled with Bolton-Hunter reagent (sp act, $2,100-3,200 \mathrm{Ci} / \mathrm{mMol}$ ) (32) were added in $0.1 \mathrm{ml}$ of buffer. After a further $24 \mathrm{~h}$ incubation, $0.1 \mathrm{ml}$ of goat anti-rabbit gamma globulin serum were added (final dilution 1:150). The reaction was allowed to incubate further $24 \mathrm{~h}$ at $4^{\circ} \mathrm{C}$, and then centrifuged at $3,000 \mathrm{~g}$ for 25 $\mathrm{min}$. The supernatants were aspirated, and the precipitated radioactivity counted. The receptor content of the specimens was expressed as nanograms of insulin receptors $/ 0.1 \mathrm{mg}$ of either protein or DNA. This assay is sensitive to unlabeled receptor concentration as low as 1.0 $\mathrm{ng} / \mathrm{ml}$; the interassay coefficient of variation is $9.0 \%$ and the intraassay variation is $5.0 \%$. The cross-reactivity with the IGF-I receptor is $<3 \%$.

Insulin receptor tyrosine kinase assay. Phosphotransferase activity of wheat germ agglutinin-purified insulin receptors was determined by preincubating $10 \mathrm{ng}$ of receptors with various concentrations of insulin for $60 \mathrm{~min}$ at $22^{\circ} \mathrm{C}$ in a buffer containing $50 \mathrm{mM}$ Hepes (pH 7.4), $0.1 \%$ Triton X-100, $150 \mathrm{mM} \mathrm{NaCl}, 1 \mathrm{mM}$ PMSF. Next, $2 \mathrm{mM} \mathrm{MnCl} \mathrm{m}_{2}, 10$ $\mathrm{mM} \mathrm{MgCl}$ and $5 \mu \mathrm{M}\left[\gamma{ }^{32} \mathrm{P}\right] \mathrm{ATP}(2 \mu \mathrm{Ci} /$ tube $)$ were added for $30 \mathrm{~min}$ at $22^{\circ} \mathrm{C}$ in the presence of $1 \mathrm{mM} \mathrm{Na}_{3} \mathrm{VO}_{4}$ to inhibit dephosphorylation reactions. The synthetic substrate poly(Glu-Tyr, 4:1) was then added to a final concentration of $2.5 \mathrm{mg} / \mathrm{ml}$, and the incubation continued for $30 \mathrm{~min}$ at $22^{\circ} \mathrm{C}$. Finally, $40 \mu \mathrm{l}$ aliquots were spotted on $4-\mathrm{cm}^{2}$ disks of $3 \mathrm{M}$ paper (Whatman Inc., Clifton, NJ) and dried. Disks were washed in four changes of $10 \%$ TCA containing $10 \mathrm{mM}$ sodium pyrophosphate and in a final acetone wash. Radioactivity was determined by scintillation counting. The background controls were determined from duplicate reactions lacking poly(Glu-Tyr).

Immunostaining. Specimens of normal breast tissue and breast cancer were fixed in Bouin's solution and embedded in paraffin. Sections of $\sim 5 \mu \mathrm{m}$ thick were cut for staining. Counterstaining was with Harris hematoxylin. Immunoperoxidase staining was performed as described by Sternberger (37) as previously reported (38). After the sections were deparaffined by xylol treatment, they were incubated $2 \mathrm{~h}$ at $24^{\circ} \mathrm{C}$ with either normal mouse IgG or insulin receptor monoclonal antibody each at $7 \mathrm{nM}$. This incubation was followed by incubation with $1 / 1,000$ anti-mouse IgG peroxidase for $30 \mathrm{~min}$ at $24^{\circ} \mathrm{C}$. After rinsing, the peroxidase activity was demonstrated by a solution of 225 $\mu \mathrm{M}$ diaminobenzidine buffer with $0.01 \% \mathrm{H}_{2} \mathrm{O}_{2}$. A second negative control was carried out by preincubating sections with $5 \mu \mathrm{M}$ insulin.

Estrogen and progesterone receptor measurements. Estrogen and progesterone receptors were also measured in breast carcinomas. For this purpose, frozen breast tissue specimens were powdered in a Dismembrator (Braun, Melsugen, FRG), suspended 1:8 (wt/vol) in 10 mM PBS buffer, pH 7.4, containing $1.5 \mathrm{mM}$ EDTA, $10 \mathrm{mM}$ mono- 
thioglycerol, $10 \mathrm{mM}$ sodium molybdate and $10 \%$ glycerol, and centrifuged at $10,000 \mathrm{~g}$ for $50 \mathrm{~min}$ at $4^{\circ} \mathrm{C}$. Estrogen and progesterone receptors were then measured in the supernatants according to the following procedure $(16,39)$ : to $0.1 \mathrm{ml}$ of cytosol either tritiated estradiol (in the presence or the absence of increasing concentration of unlabeled diethylstilbestrol as a competitor), or tritiated progesterone analogue ORG 2058 (in the presence or the absence of increasing concentration of unlabeled ORG 2058), were added for measuring specific estrogen or progesterone receptor sites, respectively. After incubation at $4^{\circ} \mathrm{C}$ for $16 \mathrm{~h}$, the free hormone was separated from hormone bound to receptors by absorption to dextran-coated charcoal $(16,39)$. The receptor bound radiolabeled hormone in the supernatant was measured by a beta-counter scintillation and the data analyzed according to the method of Scatchard (40). The receptor content of the tissue specimens was expressed as fmoles of receptors/mg of cytosol protein. Values higher than $10 \mathrm{fmol} / \mathrm{mg}$ protein were considered as positive for both estrogen and progesterone receptors $(16,39)$.

Other methods. Protein was measured by the method of Bradford (41) and DNA according to the method of Labarca and Paigen (42).

\section{Results}

Insulin receptor $R I A$. Studies were undertaken to examine the reactivity of both normal breast tissue and breast cancer tissue in the radioimmunoassay (Fig. 1). Progressive dilutions of these tissues generated competition-inhibition curves that were parallel to the highly purified insulin receptor standard, indicating the immunological similarity of the receptors in these extracts. Breast cancer tissue, however, had significantly more insulin receptors than normal breast tissue. Increasing amounts of MCF-7 cells, a human breast cancer cell line, also generated a competition-inhibition curve that was parallel to the purified standard and had an IR content that was also greater than normal breast tissue.

Survey of breast cancer. Next we evaluated the insulin receptor content of 159 breast carcinomas specimens, 27 specimens of normal breast tissue obtained during cancer surgery, and 9 specimens of breast fibroadenoma (Fig. 2). The average content of insulin receptors (IRs) in the breast carcinoma specimens was $6.15 \pm 3.69 \mathrm{ng} \mathrm{IR} / 0.1 \mathrm{mg}$ protein (mean $\pm \mathrm{SD}$; me-

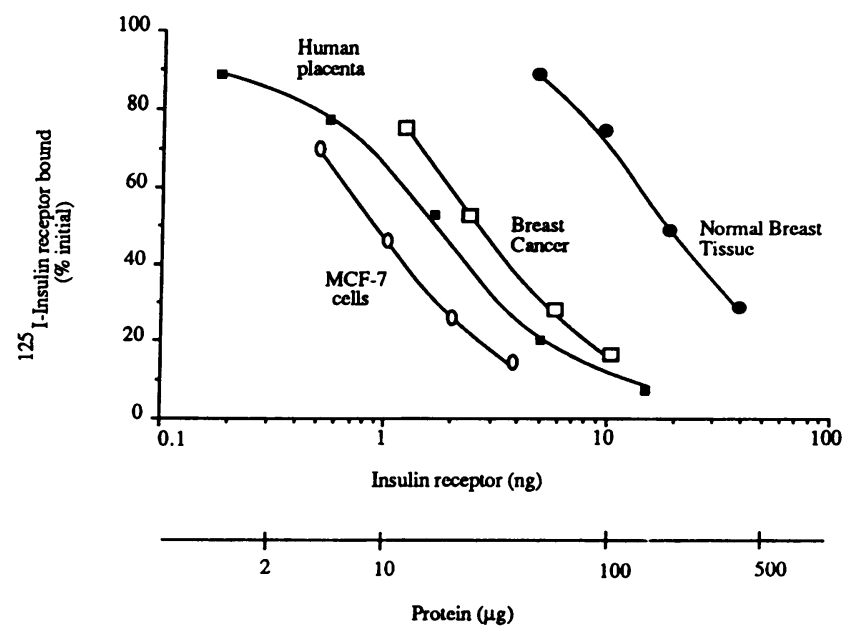

Figure 1. Competition-inhibition curves for the purified placenta insulin receptor standard $(\square)$ and extracts of human MCF-7 breast cancer cells (O), breast cancer tissue ( $\square$ ), and normal breast tissue (•) on the binding of labeled insulin receptors to antireceptor antiserum. A representative of three experiments is shown.

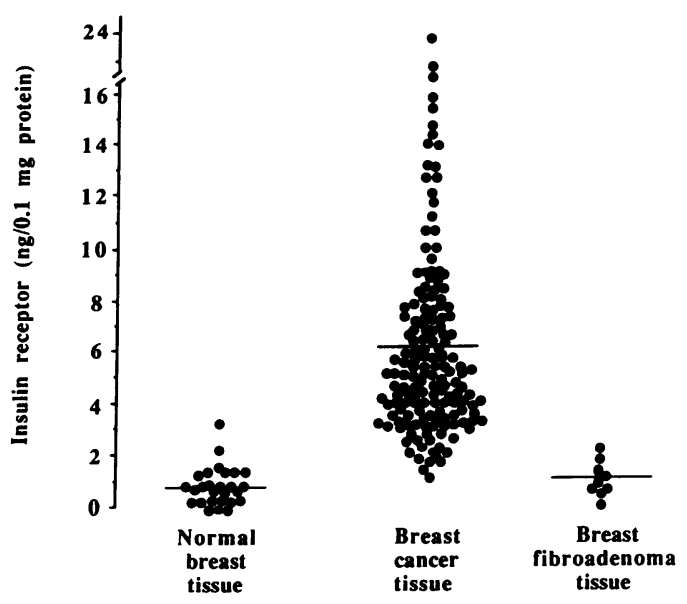

Figure 2. Insulin receptor content in normal breast tissue, breast cancer, and breast fibroadenoma specimens.

dian 5.12; range 1.16-23.77; Fig. 2). This value was much higher than the mean value obtained in normal breast tissues (0.95 $\pm 0.68 \mathrm{ng}$ IR/0.1 mg protein; $P<0.001$; range $0.11-3.45)$. A comparable content in IR was found in 6 normal specimens obtained from reduction mammoplasty $(0.84 \pm 0.28 \mathrm{ng}$ IR/0.1 mg protein, mean $\pm \mathrm{SD}$ ). All normal breast tissues except three (containing 1.34, 2.57, and 3.45 IR/0.1 mg protein) had fewer IRs than the lowest value obtained for breast cancer tissue (1.16 ng IR/0.1 mg protein) (Fig. 2). This significant difference between normal breast tissue and breast cancer tissue was also present when the IR content was also expressed per DNA content $(113.20 \pm 68.61$ vs. $21.52 \pm 10.10 \mathrm{ng} \mathrm{IR} / 0.1 \mathrm{mg}$ DNA, respectively, mean $\pm \mathrm{SD}, P<0.001, n=74$ cancer, 19 normal). The IR content in the fibroadenoma specimens was not significantly different from normal breast tissue $(1.09 \pm 0.51 \mathrm{ng}$ IR/0.1 mg protein, mean \pm SD) (Fig. 2). These studies demonstrated, therefore, that breast cancer tissue had high levels of immunoreactive insulin receptors.

Functional studies of the breast cancer insulin receptor. We next carried out studies to determine whether these immunoreactive insulin receptors in breast cancer tissue were functional. First, the ability of these insulin receptors to bind insulin was investigated. Sufficient tissue was available from six normal breast tissue specimens and 6 breast cancer tissue specimens to perform ligand binding studies. Solubilized receptors from normal breast tissues bound $0.51 \pm 0.30 \%$ (mean $\pm \mathrm{SD}$ ) of the labeled insulin $/ 0.1 \mathrm{mg}$ of tissue protein. Breast cancer tissues bound ninefold more insulin at $4.60 \pm 2.53 \%$ $($ mean $\pm \mathrm{SD}) / 0.1 \mathrm{mg}$ of tissue protein $(P<0.01)$ (Table I).

Second, the tyrosine kinase activity of the breast cancer insulin receptor was studied. The ability of partially purified breast cancer and normal breast IR preparations from the same patient to phosphorylate the exogenous synthetic substrate poly(Glu-Tyr, 4:1) was measured (Table II). Normal breast and breast carcinoma IRs had both similar basal tyrosine kinase activity, and insulin stimulated this function in a dose dependent manner (Table II).

Morphological localization of the breast cancer insulin receptor. We next investigated which cell type contained insulin receptors in the breast cancer specimens. Surgical specimens of breast cancer contain, in addition to cancer cells, fat, stromal, vascular and inflammatory cells. To identify cells expressing 
Table I. Insulin Receptor Studies in the Same Specimens of Breast Cancer Tissue and Normal Breast Tissue

\begin{tabular}{|c|c|c|c|c|}
\hline \multirow{2}{*}{$\begin{array}{c}\text { Patient } \\
\text { No. }\end{array}$} & \multicolumn{2}{|c|}{ Breast cancer specimens } & \multicolumn{2}{|c|}{ Normal breast tissue specimens } \\
\hline & IR RIA* & $\mathbf{B} / \mathbf{T}^{t}$ & IR RIA* & $\mathrm{B} / \mathrm{T}^{*}$ \\
\hline & \multicolumn{3}{|c|}{ (\%) } & (\%) \\
\hline 1 & 15.8 & 8.3 & 0.9 & 0.4 \\
\hline 2 & 4.6 & 1.2 & 0.9 & 0.6 \\
\hline 3 & 6.6 & 3.8 & 1.0 & 0.6 \\
\hline 4 & 15.2 & 4.3 & 0.5 & 0.4 \\
\hline 5 & 14.4 & 3.3 & 1.3 & 0.7 \\
\hline \multirow[t]{3}{*}{6} & 12.9 & 6.7 & 1.2 & 0.5 \\
\hline & 11.6 (mean) & 4.6 (mean) & 1.0 (mean) & 0.5 (mean) \\
\hline & 4.4 (SD) & $2.5(\mathrm{SD})$ & 0.2 (SD) & $0.3(\mathrm{SD})$ \\
\hline
\end{tabular}

* Insulin receptor measured by radioimmunoassay (nanogram/0.1 mg. protein); ${ }^{t}$ Insulin receptor measured by specific ${ }^{125}$ I-insulin binding (percent $\mathrm{B} / \mathrm{T} / 0.1 \mathrm{mg}$ protein).

insulin receptors, immunohistochemical analysis using a monoclonal antibody to the alpha subunit of the human insulin receptor (33) was carried out in six breast cancer specimens. This analysis clearly showed an intense cytoplasmic/membrane staining in $100 \%$ of the tumor epithelial cell nests. There was, however, occasional differences in staining between cells suggesting heterogeneity in IR content. On the contrary, no specific immunostaining for the insulin receptor was seen in the stromal or inflammatory cells (Fig. 3). Little or no staining of the epithelial cells of normal breast tissue was observed (data not shown). This latter observation most likely reflects the sevenfold decreased IR content in normal breast tissue.

\section{Correlations (43)}

To assess whether the IR content was related to other characteristics of the breast tumors, we first examined the distribution of IR. The scatter diagram in Fig. 2 indicates that the IR values of breast cancer specimens had a unimodal distribution skewed toward higher values. Transforming these values by computing their natural logarithms produced a normal shaped distribution (Fig. 4). The frequency histogram in Fig. 4 was comparable to the superimposed normal reference curve that has the same mean (1.66) and standard deviation $(0.54)$ as the logarithmic values. We then analyzed the relationship of the

Table II. Comparison of Tyrosine Kinase Activity in Insulin Receptors from Breast Cancer and Adjacent Normal Breast Tissue

\begin{tabular}{lccc}
\hline & \multicolumn{3}{c}{ Insulin $(n M)$} \\
\cline { 2 - 4 } & 0 & 1.0 & 100 \\
\hline Normal & $0.435 \pm 0.021$ & $0.499 \pm 0.045$ & $0.648 \pm 0.024$ \\
Cancer & $0.460 \pm 0.032$ & $0.531 \pm 0.033$ & $0.598 \pm 0.119$
\end{tabular}

Phosphorylation of Poly(Glu/Tyr). Insulin receptors were purified from breast cancer tissue and adjacent normal breast tissue obtained from the same patient and purified by wheat germ agglutinin chromatography. Phosphorylation of the exogenous substrate (poly Glu/ Tyr 4:1) was then measured. Each value is the mean $\pm S D$ of ${ }^{32} \mathrm{P}$ incorporated/nanogram receptor for triplicate determinations. contents of IR to other variables. These were grouped into three categories; host variables (age, body mass index, and menopausal status), tumor variables (histological type, grade, size, and nodal involvement), and other hormone receptors (estrogen receptor and progesterone receptor).

Relationship of IR to host variables. Three host variables, patient's age, body mass index, and menopausal status, were obtained for 156,138 , and 156 patients, respectively. The patient's age was only modestly correlated with the IR values ( $r$ $=0.14 ; P=0.85$ ).

Of the 156 patients whose menopausal status could be ascertained, there were $44(28.2 \%)$ who were premenopausal and $112(71.8 \%)$ who were postmenopausal. The values for IR in the pre and post menopausal groups, were $5.0 \pm 1.7$ and $5.3 \pm 1.70 .1 \mathrm{ng} / \mathrm{mg}$ protein respectively $($ mean $\pm \mathrm{SD})(P=0.63)$. Body mass index did not correlate with IR $(r=0.02, P=0.42)$.

Relationship of IR to tumor properties. Information about histological type was available for $149(93.7 \%)$ of the tumors (Table III). No difference was seen between the five categories. Classification of tumors according to grade was performed in 121 specimens of ductal and mixed carcinomas. The IR content in the three groups was $4.5 \pm 1.2(n=5), 4.8 \pm 1.7(n=73)$, and $6.2 \pm 1.6(n=43) \mathrm{ng}$ IR/0.1 $\mathrm{mg}$ protein in the $(a)$ well, $(b)$ middle, and $(c)$ poorly differentiated tumors, respectively (mean $\pm \mathrm{SD}$ ). Although there was considerable overlap between the distributions of IR in these three categories, by one-way analysis of variance (ANOVA) (Fig. $5 \mathrm{~A}$ ), the mean level in the undifferentiated category $(c)$ was significantly higher than from the mean values observed in the other two categories $(P$ $=0.003$ ).

Nodal involvement was known in 131 patients: no relationship was found between IR content and nodal involvement (Fig. $5 \mathrm{~B}$ ). The group of 61 node negative patients had an insulin receptor content of $5.1 \pm 1.8 \mathrm{ng} / 0.1 \mathrm{mg}$ protein and the group of 70 node positive patients had an IR content $5.7 \pm 1.7$ $\mathrm{ng} / 0.1 \mathrm{mg}$ protein (mean $\pm \mathrm{SD}$ ). These differences were not statistically significant.

We next studied the relationship between IR and tumor size (Fig. $5 \mathrm{C}$ ). The IR content in three groups $(<2 \mathrm{~cm}, 2-5$ $\mathrm{cm}$, and > 5) were 4.6 $\pm 1.6,6.0 \pm 1.8$, and 6.4 $\pm 1.8 \mathrm{ng} \mathrm{IR} / 0.1$ mg protein, respectively (mean $\pm \mathrm{SD}$ ). According to one-way ANOVA, the mean IR content increase related to tumor size could not be explained by chance alone $(P=0.014)$.

Relationship of IR to other hormone receptor levels. The Spearman correlations between insulin receptor measurements and estrogen and progesterone receptors, were $0.17(P$ $=0.035)$ and $0.10(P=0.20)$, respectively.

\section{Other studies}

To ascertain whether elevated insulin receptors were present in glandular malignancies other than breast cancer, we also evaluated the insulin receptor content in nonmalignant thyroid tissue specimens, and thyroid carcinomas. No difference in insulin receptors was found between thyroid carcinomas and nonmalignant thyroid tissues (Table IV).

\section{Discussion}

In the present study, we have employed a specific RIA to measure insulin receptor content in samples of breast carcinoma tissues from 159 patients. The measurement of insulin receptors by radioimmunoassay has certain advantages over 

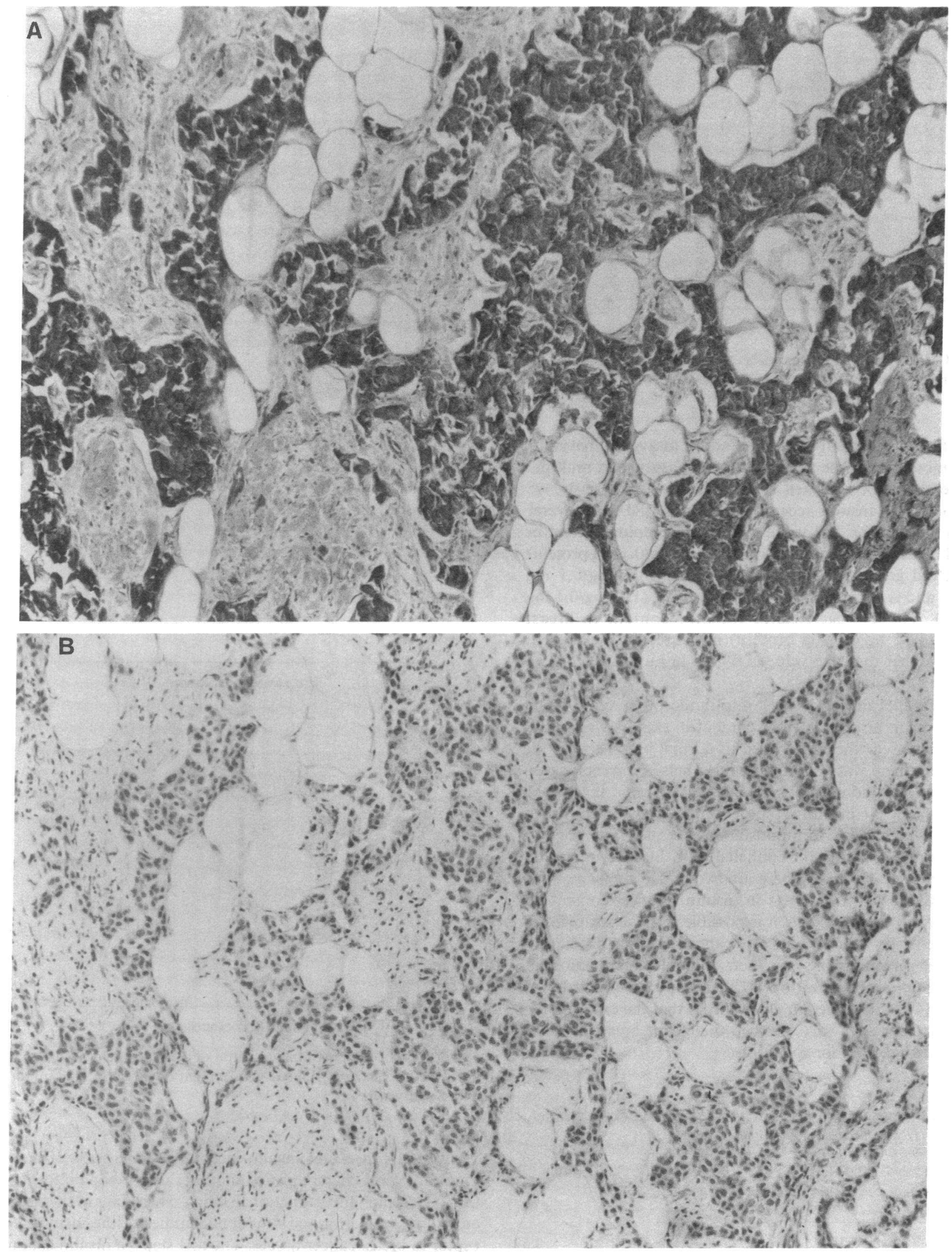

Figure 3. Representative sections of a ductal breast cancer. $(A)$ Indirect immunoperoxidase staining of the insulin receptor with insulin receptor monoclonal antibody MA-20. The specific staining, with various intensity, is located only in the cytoplasm of malignant epithelial cells while the stromal and other cells are not stained. Some heterogeneity in the intensity of malignant cell staining is evident at higher magnifications. $(B)$ Control studies in an adjacent section treated in the same manner as $A$ but preincubated with $5 \mu \mathrm{M}$ insulin. No immune staining of epithelial cells is present. All sections were counterstained with Harris hematoxylin. Magnification $(A$ and $B), 25$. 


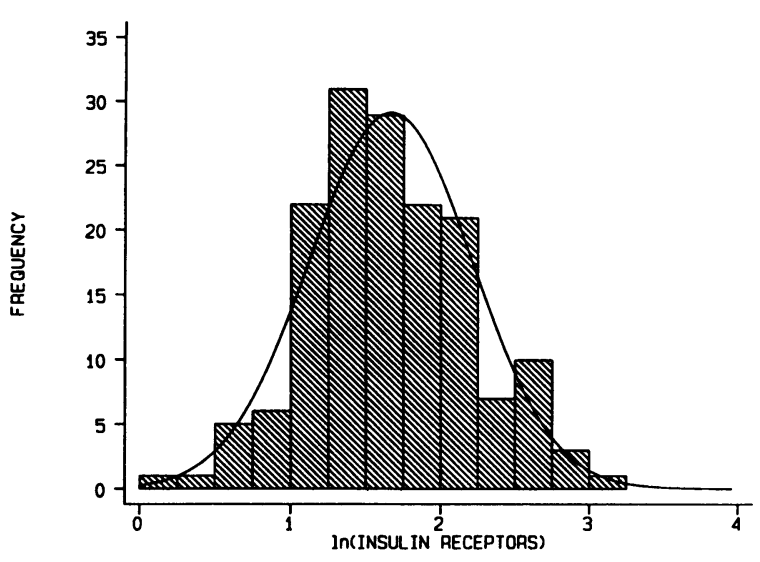

Figure 4. Histogram of a normal reference curve, and the distribution of the natural logarithm of the IR content.

conventional ${ }^{125} \mathrm{I}$-insulin ligand binding assays in that very small amounts of tissue are needed $(1 \mathrm{mg} /$ assay) and multiple specimens may be analyzed in a single assay. Previously, we have measured insulin receptor content by RIA in several human tissues (32). The value for insulin receptor content in normal breast tissue measured herein $(0.95 \mathrm{ng} / 0.1 \mathrm{mg}$ protein $)$ is threefold greater than that for fat tissue $(0.31 \mathrm{ng} / 0.1 \mathrm{mg}$ protein) and is comparable to that for muscle $(1.13 \mathrm{ng} / 0.1 \mathrm{mg}$ protein). The average insulin receptor content in breast cancers $(6.15 \mathrm{ng} / 0.1 \mathrm{mg}$ protein) measured in the present study is higher than the value observed in human liver (4.76 $\mathrm{ng} / 0.1 \mathrm{mg}$ protein).

In all breast tissue samples, insulin receptors were present and the mean insulin receptor content in tumors was signifcantly increased when compared to normal breast tissue. We found that there was very little overlap between receptor content of cancers and normal breast tissue. However, there was a large range in the insulin receptor content between the different cancer specimens. Immunostaining revealed that receptors were mainly in malignant epithelial cells, but not in stromal and inflammatory cells. There are two possible explanations, therefore, for the wide range in insulin receptor content between breast cancers. First, it is possible that the stromal/epithelial cell ratio varied in different cancers leading to a dilution of the IR protein in the specimen. A similar observation has been made concerning the HER 2/neu protein in breast cancers $(44,45)$. A second possibility is that the expression of the IR in fact does vary between malignant breast epithelial cells in different tumor specimens.

Table III. Distribution of Histological Types and Properties of the $\ln (I R)$ by Histological Type

\begin{tabular}{lrrrr}
\hline & & & \multicolumn{2}{c}{ In (IR) } \\
\cline { 4 - 5 } $\begin{array}{l}\text { Histological } \\
\text { type }\end{array}$ & Number & Percent & Mean & SD \\
\hline Ductal & 108 & 72.5 & 1.71 & 0.57 \\
Papillary & 3 & 2.0 & 1.86 & 0.58 \\
Mixed & 13 & 8.7 & 1.63 & 0.46 \\
Lobular & 22 & 14.8 & 1.60 & 0.51 \\
Other & 3 & 2.0 & 1.04 & 0.56 \\
& & & & \\
\hline
\end{tabular}
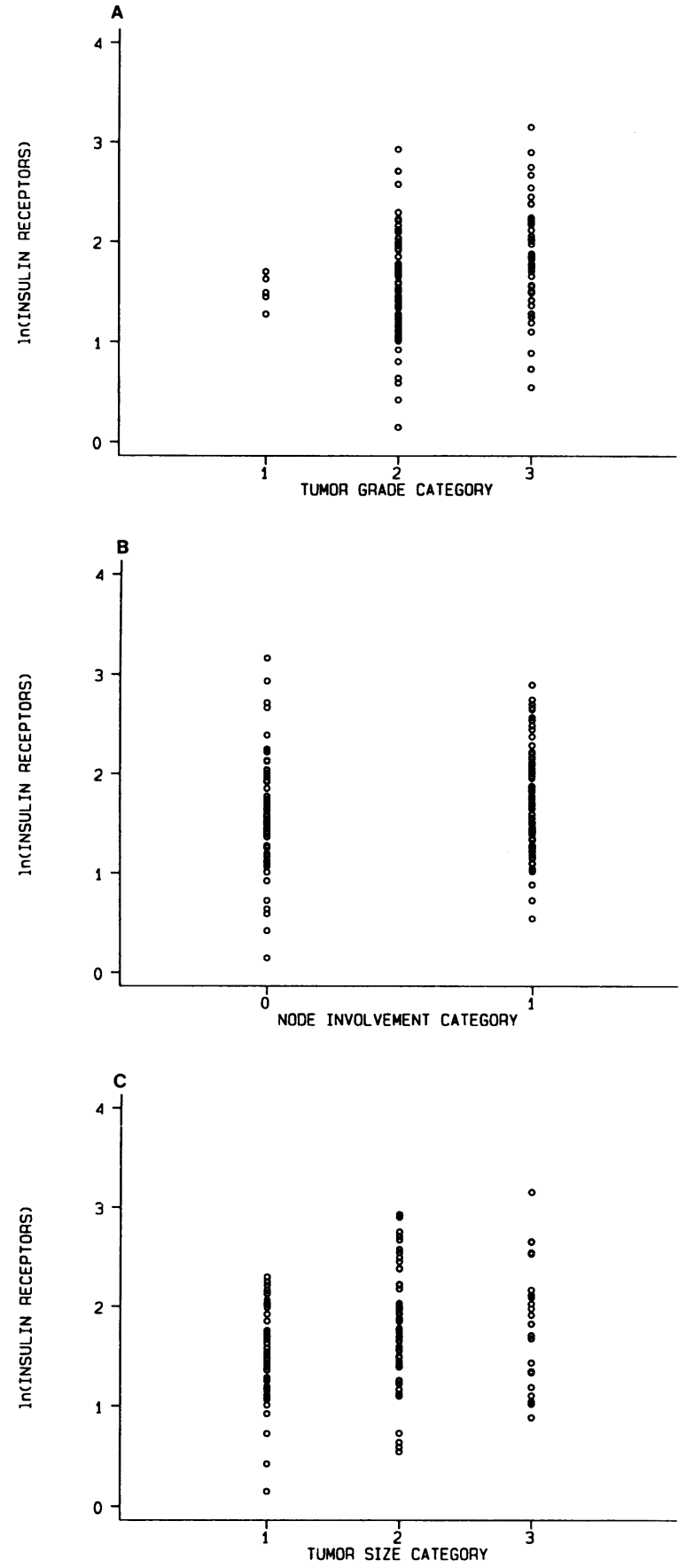

Figure 5. Plots of the natural logarithm of the IR content versus tumor grade category $(A)$, node involvement category $(B)$, and tumor size category $(C)$.

The RIA measures insulin receptors on the basis of their immunological characteristics and does not provide information concerning their functional status. Therefore, in the present study, we performed functional studies of the insulin receptor in breast cancer tissues. The first steps in insulin action are binding of the hormone to the receptor $\alpha$ subunit with subsequent activation of tyrosine kinase activity in the $\beta$ subunit. Accordingly, ligand binding analyses were carried out that indicated insulin receptor binding was elevated in breast carcinomas, suggesting that the elevated insulin receptors, as 
Table IV. Insulin Receptor Content in Thyroid Tissue Specimens

\begin{tabular}{ll}
\hline \multicolumn{1}{c}{ Thyroid tissue } & IR RIA* \\
\hline Normal $(n=5)$ & $8.2 \pm 5.6$ \\
Grave's disease $(n=2)$ & $6.9 \pm 2.7$ \\
Carcinoma $(n=6)$ & $8.4 \pm 6.2$ \\
\hline
\end{tabular}

Values are mean $\pm \mathrm{SD}$.

* Insulin receptor measured by radioimmunoassay (nanogram/0.1 mg protein).

measured by RIA, were also able to bind insulin. Next, the tyrosine specific kinase activity of these breast cancer insulin receptors was analyzed and found to be responsive to insulin. Thus, the insulin receptors in breast cancer were increased and retained their functional characteristics.

An elevated content of insulin receptors does not appear to be a characteristic feature of all cancers. For instance, in the present study, we found no elevation in insulin receptor content in differentiated thyroid carcinomas. Also, we have previously reported that in rat hepatomas, insulin receptor content was decreased when compared to normal liver (46). In addition, an elevated content of insulin receptors is not a feature of all breast tumors since in the present studies there was no elevation of receptor content in breast fibroadenomas.

Employing ligand binding studies, receptors for other polypeptide hormones that activate tyrosine kinase in their receptors have been investigated in human breast cancer (47). The receptors for both (IGF-I) and epidermal growth factor (EGF) have been reported to be elevated in some, but not all tumors (47). Also the HER 2/neu protein, a putative receptor closely related to the EGF receptor, is elevated in $25-30 \%$ of breast cancers (45). In a recent study, tyrosine kinase activity was measured in human breast cancers and was found to be signifcantly increased when compared to benign breast tumors and normal breast tissue (48). Our present observation of an insulin responsive insulin receptor tyrosine kinase activity in breast cancers indicates that, in addition to EGF, IGF-I, and HER $2 /$ neu receptors, another contribution to the increased tyrosine kinase activity in breast cancer is from the increased insulin receptor content.

Studies reveal that the ligand for the IGF receptor, IGF-I, is produced by breast cancer stromal cells (49). Thus, a paracrine relationship for this ligand-receptor system may exist in certain breast carcinomas and contribute to increased cancer agressiveness. The IGF-I receptor has sequence and structural homology to the insulin receptor, and IGF-I has sequence and structural homology to insulin. Moreover, IGF-I can also interact with and activate the insulin receptor. Thus, a paracrine relationship may exist whereby IGF-I stimulates insulin receptors in breast cancer leading to increased insulin receptor signaling.

The mechanism(s) whereby insulin receptors are increased in human breast cancers remain speculative. There are several possibilities. Since the genes for some oncogenes including c-myc, int-2, c-erbB-2 and the related HER-2/neu may be amplified in human breast carcinomas (44), it is possible that the insulin receptor gene is also amplified. Alternatively, since structural gene rearrangement occurs in human breast carcinomas (50), it is possible that the insulin receptor gene is al- tered in this tumor and consequently insulin receptor mRNA is overexpressed.

The clinical significance of the observation that insulin receptors are markedly elevated in nearly all breast cancer specimens analyzed is unknown. In the present study, analysis of IR content was correlated with other parameters. On one hand, in ductal and mixed tumors there was a significant correlation with IR and tumor grading, tumor properties reflecting tumor agressiveness. There was also a significant correlation with IR and tumor size. Tumor size most likely reflects both inherent tumor aggressiveness and the duration of tumor growth. These two observations suggested therefore that less differentiated and more aggressive tumors may have more insulin receptors. The possibility also exhibits, however, that the duration of tumor growth may lead to the selection of cancer cells with a higher IR content. On the other hand, there was not a correlation with IR content and lymph node involvement, another reflection of tumor aggressiveness and duration of tumor growth. Also, there was a significant positive correlation with IR content and estrogen receptor content, a favorable prognostic indicator. Since insulin regulates breast cancer cell growth, and insulin receptors are elevated in breast cancer tissues, it is likely that insulin and its receptor plays a role in breast cancer biology. However, whether IR content predicts a negative or positive outcome in these tumors remains to be elucidated. These observations, although obtained in a limited number of patients, raise the possibility, therefore, that the insulin receptor may play a role in the biology of breast cancers and that measurement of the insulin receptor content should be useful, in conjunction with other parameters, in the classification of breast tumors.

\section{Acknowledgments}

We thank Dr. Caterina Lanza, M.D., Servizio di Anatomia Patologica, Presidi Ospedalieri Unificati S. Curròe S. Luigi Gonzaga, USL 34, Catania, Italy, for the histological examination and classification of breast specimens.

This work was supported in part by Associazione Italiana per la Ricerca sul Cancro, Italy; Regione Siciliana, Italy, grant No. 105/M.1987; Consiglio Nazionale delle Ricerche, Italy, No. 88.00682.04; and the John A. Kerner Foundation.

\section{References}

1. Dickson, R. B., and M. E. Lippman. 1987. Estrogenic regulation of growth and polypeptide growth factor secretion in human breast carcinoma. Endocr. Rev. 8:29-43.

2. Engel, L. W., and N. A. Young. 1978. Human breast carcinoma cells in continuous culture: a review. Cancer Res. 38:4327-4339.

3. Furlanetto, R. W., and J. N. DiCarlo. 1984. Somatomedin-C receptors and growth effects in human breast cells maintained in longterm tissue culture. Cancer Res. 44:2122-2128.

4. Benson, E. A., and I. M. Holdaway. 1982. Regulation of insulin binding to human mammary carcinoma. Cancer Res. 42:1137-1141.

5. Lippman, M. E. 1985. Growth regulation of human breast cancer. Clin. Res. 33:375-382.

6. Burke, R. E., and W. L. McGuire. 1978. Nuclear thyroid hormone receptors in a human breast cancer cell line. Cancer Res. 38:3769-3773.

7. Harmon, J. T., and R. Hilf. 1976. Identification and characterization of the insulin receptor in the R3230AC mammary adenocarcinoma of the rat. Cancer Res. 3993-4000.

8. Shiu, R. P. C. 1979. Prolactin receptors in human breast cancer cells in long-term tissue culture. Cancer Res. 39:4381-4386.

9. Pollak, M. N., G. Polychronekos, S. Yousef, and M. Richard. 
1988. Characterization of insulin-like growth factor I (IGF-I) receptors of human breast cancer cells. Biochem. Biophys. Res. Commun. 1:326-331.

10. Lippman, M. E., C. K. Osborne, R. Knazek, and N. Young. 1977. In vitro model systems for the study of hormone-dependent human breast cancer. N. Engl. J. Med. 154-159.

11. Calaf, G., F. Garrido, C. Moyano, and R. Rodriguez. 1986. Influence of hormones on DNA synthesis of breast tumors in culture. Breast Cancer Res. Treat. 8:223-232.

12. Holdaway, I. M., and H. G. Friesen. 1976. Correlation between hormone binding and growth response of rat mammary tumor. Cancer Res. 36:1562-1567.

13. Iacobelli, S., and C. Natoli. 1985. Growth promoting influences of estradiol, epidermal growth factor, and insulin on human breast cancer: evidence for differential mechanism of action on tumor cells in vitro. Breast Cancer Res. Treat. 6:255-256.

14. Soto, A. M., and C. Sonnenschein. 1987. Cell proliferation of estrogen-sensitive cells: the case for negative control. Endocr. Rev. 8:44-52.

15. Kasid, A., and M. D. Lippman. 1987. Estrogen and oncogene mediated growth reulation of human breast cancer cells. J. Steroid Biochem. 27:465-470.

16. Wittliff, J. L. 1984. Steroid hormone receptors in breast cancer. Cancer (Phila.). 53:630-643.

17. Osborne, C. K., M. D. Yochmowitz, W. A. Knight, and W. L. McGuire. 1980. The value of estrogen and progesterone receptor in the treatment of breast cancer. Cancer (Phila.). 46:2884-2888.

18. Scholl, S., and M. E. Lippmann. 1984. Methods and clinical use of receptor assay. In Breast Cancer: Diagnosis and Management. G. Bonadonna, editor. John Wiley \& Sons, New York. 74-108.

19. Legha, S. S. 1988. Tamoxifen in the treatment of breast cancer. Annals Intern. Med. 109:219-228.

20. Maas, H., W. Jonat, G. Stolzenbach, and G. Trams. 1980. The problem of nonresponding estrogen receptor-positive patients with advanced breast cancer. Cancer (Phila.). 46:2835-2837.

21. Sporn, M. B., A. B. Roberts, and J. S. Driscoll. 1985. Principles of cancer biology: growth factor and differentiation. In Cancer Principles and Practice of Oncology. DeVita V. T., Jr., S. Hellman, and S. A. Rosenberg, editors. J. B. Lippincott Co., Philadelphia. 49-65.

22. J. C. Heuson, A. Coune, and R. Heimann. 1967. Cell proliferation induced by insulin in organ culture of rat mammary carcinoma. Exp. Cell. Res. 45:351-360.

23. Welsch, C. W., G. Calaf De Iturri, and M. J. Brennan. 1976. DNA synthesis of human, mouse, and rat mammary carcinomas in vitro. Cancer (Phila.). 38:1272-1281.

24. Shafie, S. M., and R. Hilf. 1978. Relationship between insulin and estrogen binding to growth response in 7, 12-dimethylbenz(a)anthracene-induced rat mammary tumors. Cancer Res. 38:759-764.

25. Van Der Burg, B., G. R. Rutteman, M. A. Blankenstein, S. W. De Laat, and E. J. J. Van Zoelen. 1988. Mitogenic stimulation of human breast cancer cells in a growth factor-defined medium: synergistic action of insulin and estrogen. J. Cell. Physiol. 134:101-108.

26. Gross, G. E., D. H. Boldt, and C. K. Osborne. 1984. Perturbation by insulin of human breast cancer cell kinetics. Cancer Res. 44:3570-3575.

27. Osborne, C. K., G. Bolan, M. E. Monaco, and M. E. Lippman. 1976. Hormone responsive human breast cancer in long-term tissue culture: effect of insulin. Proc. Natl. Acad. Sci. USA. 73:4536-4540.

28. Mountjoy, K. G., G. J. Finlay, and I. M. Holdaway. 1987. Abnormal insulin-receptor down regulation and dissociation of down regulation from insulin biological action in cultured human tumor cells. Cancer Res. 47:6500-6504.

29. Osborne, C. K., M. E. Monaco, M. E. Lippman, and C. R. Kahn. 1978. Correlation among insulin binding, degradation, and bio- logical activity in human breast cancer cells in long-term tissue culture. Cancer Res. 38:94-102.

30. Mountjoy, K. G., I. M. Holdaway, and G. J. Finlay. 1983. Insulin receptor regulation in cultured human tumor cells. Cancer Res. 43:4537-4542.

31. Holdaway, I. M., and H. G. Friesen. 1977. Hormone binding by human mammary carcinoma. Cancer Res. 37:1946-1952.

32. Pezzino, V., V. Papa, V. Trischitta, A. Brunetti, P. A. Goodman, M. K. Treutelaar, J. A. Williams, B. A. Maddux, R. Vigneri, and I. D. Goldfine. 1989. Human insulin receptor radioimmunoassay: applicability to insulin-resistant states. Am. J. Physiol. 257:E451-457.

33. Forsayeth, J. R., A. Montemurro, B. A. Maddux, R. DePirro, and I. D. Goldfine. 1987. Effect of monoclonal antibodies on human insulin receptor autophosphorylation, negative cooperativity, and down-regulation. J. Biol. Chem. 262:4134-4140.

34. Forsayeth, J., B. A. Maddux, and I. D. Goldfine. 1986. Biosynthesis and processing of the human insulin receptor. Diabetes. 35:837-846.

35. World Health Organization. 1981. Histological typing of breast tumors. WHO, Geneva. 1-48.

36. Bloom, H. I. G., and W. W. Richardson. 1957. Histological grading and prognosis in breast cancer. Br. J. Cancer. 11:359-377.

37. Sternberger, L. A. 1979. The unlabeled antibody peroxidaseantiperoxidase (PAP) method. In Immunocytochemistry. L. A. Stemberger, editor. John Wiley \& Sons, New York. 104-112.

38. Vannelli, B. G., C. Orlando, T. Barni, A. Natali, M. Serio, and G. C. Balboni. 1986. Immunostaining of transferrin and transferrin receptor in human seminiferous tubules. Fertil. Steril. 45:536-541.

39. Piffanelli, A., S. Fumero, D. Pelizzola, G. P. Berruto, L. Ricci, and G. Giovannini. 1982. Uniformated D.C.C. method for estradiol and progesterone receptor assay on tumor tissue. LAB J. Res. Lab. Med. 1:13-21.

40. Scatchard, G. 1949. The attraction of proteins for small molecules and ions. Ann. NY Acad. Sci. 51:660-672.

41. Bradford, M. M. 1976. A rapid and sensitive method for the quantitation of microgram quantities of protein utilizing the principle of protein-dye-binding. Anal. Biochem. 72:248-254.

42. Labarca, C., and K. Paigen. 1980. A simple, rapid, and sensitive DNA assay procedure. Anal. Biochem. 102:344-352.

43. Myers, R. H. 1986. Classical and modern regression with applications. Duxbury Press, Boston. 155-160.

44. Ali, I. U., G. Campbell, R. Lidereau, and R. Callahan. 1988. Amplification of c-erbB-2 and aggressive human breast tumors? Science (Wash. DC). 240:1795-1798.

45. Slamon, D. J., W. Godolphin, L. A. Jones, J. A. Holt, S. G. Wong, D. E. Keith, W. J. Levin, S. G. Stuart, J. Udove, A. Ullrich, and M. F. Press. 1989. Studies of the HER-2/neu proto-oncogene in human breast and ovarian cancer. Science (Wash. DC). 244:707-712.

46. Pezzino, V., R. Vigneri, M. D. Siperstein, and I. D. Goldfine. 1979. Insulin and glucagon receptors in Morris hepatomas of varying growth rates. Cancer Res. 39:1443-1446.

47. Pekonen, F., S. Partanen, T. Makinen, and E. M. Rutanen. 1988. Receptors for epidermal growth factor and insulin-like growth factor I and their relation to steroid receptors in human breast cancer. Cancer Res. 48:1343-1347.

48. Hennipman, A., B. A. van Oirschot, J. Smits, G. Rijksen, and G. E. J. Staal. 1989. Tyrosine kinase activity in breast cancer, benign breast disease, and normal breast tissue. Cancer Res. 49:516-521.

49. Yee, D., S. Paik, G. S. Lebovic, R. R. Marcus, R. E. Favoni, K. J. Cullen, M. E. Lippman, and N. Rosen. 1989. Analysis of insulin-like growth factor I gene expression in malignancy: evidence for a paracrine role in human breast cancer. Mol. Endocrinol. 3:509-517.

50. T'Ang, A., J. M. Varley, S. Chakraborty, A. L. Murphree, and Y. K. T. Fung. 1988. Structural rearrangement of the retinoblastoma gene in human breast carcinoma. Science (Wash. DC). 242:263-266. 